\title{
ROUTES TO EQUITY MARKET INTEGRATION - THE INTERPLAY BETWEEN POLITICIANS, INVESTORS AND MANAGERS ${ }^{1}$
}

\author{
Lars Oxelheim, prof.dr. The Institute of Economic Research, Lund University, P.O.Box 7080, 220 \\ 07 LUND, Sweden, e-mail: Lars.Oxelheim@fek.lu.se and The Research Institute of Industrial \\ Economics, P.O.Box 5501, 11485 STOCKHOLM, e-mail: LarsO@IUI.se
}

\begin{abstract}
Most econometric studies of equity market integration suggest that national markets are increasingly becoming part of a global equity market. As regards the extent of this integration, however, the results are often inconclusive. Further analysis calls for a closer scrutiny of the basic requirements for perfect integration. This paper presents an analysis of market segmentation in terms of existing regulatory and informational wedges, based on conditions in the Nordic welfare states. It is found that no barriers remain to cross-border equity market transactions, nor consequently to the perfect global integration of Nordic equity markets in a capital-flow perspective. However, certain residual cross-border tax wedges do challenge the view of perfect equity market integration. Further, continuing cross-border information gaps for small and medium-sized companies indicate the presence of a two-tier equity market integration.
\end{abstract}

JEL classification: F30, F36, G15, G18, G38.

Keywords: Equity market integration, foreign equity issue, cross-listing. 


\section{ROUTES TO EQUITY MARKET INTEGRATION - THE INTERPLAY BETWEEN POLITICIANS, INVESTORS AND MANAGERS}

\section{Introduction}

Researchers and practitioners both tend to attribute today's economic crises in Asia, Russia and Latin America to the globalization of financial markets. It is assumed that existing or anticipated problems in a national market, previously handled by the government and central bank of the country concerned, are contagious and will spill over into the rest of the world. Investors act in their own interest, moving capital across national borders. Policy-makers can do nothing but look on; policy-making and regulations have lost their bite. At a time when capital controls have reappeared on government agendas, this popular view calls for a deeper analysis of the interplay between politicians, managers and investors, in order to see just how far globalization has actually gone. In the present global financial turmoil the results of such an assessment can make a crucial contribution to the search for appropriate policy prescriptions.

Over the last two decades a significant volume of research has focused on ways of measuring equity market integration from an econometric point of view. Various schools of thought have developed, but for most of them the point of departure has been much the same: the law of one price, which states that if two or more markets are integrated, then identical securities should be priced identically in them all. The controversial issue dividing the different schools concerns what "being priced identically" actually means.

One strand in the literature, which highlights identical movements, is based on the analysis of co-movements of equity-market returns (for the analysis of correlation of returns, see e.g. Eun and Shim, 1989; Hamao, Masulis and Ng, 1990; Lau and Diltz, 1994; Lin, Engle and Ito 1994; for correlation of hourly returns, see e.g. Susmel and Engle, 1994; for testing the stability of correlation coefficients, see e.g. Jorion, 1985; Kaplanis, 1988; for stability over longer periods, see e.g. Erb, Harvey and Viscanta, 1994; Ibrahimi, Oxelheim and Wihlborg, 1995; Longin and Solnik, 1995; and for stability around the Crash of 1987, see e.g. Roll, 1988; Bertero and Mayer, 1990; Arshanapalli and Doukas, 1993; King, Santana and 
Whadmani, 1994). Solnik (1996) provides an overview of correlations between industrialized markets. This strand in the literature can be regarded as the main one. Whereas measuring co-movements in isolation leads to conclusions in terms of weak integration, measures of strong integration also involve the analysis of return gaps.

Most schools focusing on strong integration also start from the law of one price, but after risks have been taken into account. In studies adopting this more stringent definition of integration the thrust of the analysis can vary from the role of currency risk (see e.g. Jorion, 1989), to the long-term differences in riskadjusted returns (see e.g. Ibbotson, Siegel and Love, 1985), to optimal international asset allocation (see e.g. Glen and Jorion 1993; Odier and Solnik, 1993), to international asset pricing with extended CAPM (see e.g. Black, 1974; Stapleton and Subrahmanyam, 1977; Errunza and Losq, 1985; Eun and Janakiramanan, 1986; Hietala, 1989), to home country preference bias (see e.g. French and Poterba, 1991; Cooper and Kaplanis, 1994; Tesar and Werner, 1995), to the international pricing of risks (see e.g. Jorion and Schwartz, 1986; Gultekin, Gultekin and Penati, 1989, Harvey, 1991; Dumas, 1994), to international asset pricing with extended APT (see. e.g. Cho, Eun and Senbet, 1986; Korajczyk and Viallet, 1989; Bansal, Hsieh and Viswanathan, 1993), and finally to international asset pricing with consumption-based models (see e.g. Stultz, 1981; Wheatley, 1988).

Taken together these studies point in the same direction: towards increasing equity market integration. But when it comes to the degree of integration, the results are often inconclusive, even in the case of comparable markets and periods. This claim is supported by Naranjo and Protopapadakis (1997), who provide an overview of recent integration test results. The authors argue that the conflicting results may be partly due to the lack of an economic benchmark of integration with which the statistical tests can be compared.

In this paper I argue that before further progress can be made in measuring equity market integration, the fundamental prerequisites for integration to occur must be considered. The outcome of this initial step provides an economic benchmark per se. Then, once the extent to which these prerequisites have been met is fully recognized, it may be worth fine-tuning the measurement along the lines indicated above. The main benefit of focusing on the intricate interplay among politicians, investors and managers, and on the extent to which the fundamental requirements 
are met, is that it becomes easier to understand the sources of segmentation ${ }^{2}$ and the probability of their changing. In this way it is also possible to get a better view of the inter-temporal variation in the degree of integration. The approach boils down to an analysis of market segmentation in terms of regulatory and informational wedges. Admittedly, though, this represents a threshold view, since the regulations that exist de jure may be ineffective de facto.

Fulfillment of the various prerequisites marks out different stages $^{3}$ on the way towards perfect equity market integration. The first prerequisite is the absence of capital controls that effectively prevent cross-border equity transactions - issues and trade. The second prerequisite concerns the efficiency of internal regulations and the absence of tax wedges and prohibitive transaction costs. The third prerequisite concerns the exchange of information and the absence of cross-border information asymmetries, including differences between corporate governance systems and information costs.

The process of integration as comprised by the fulfillment of these three prerequisites is assessed here in terms of the activities of three major stakeholder groups: politicians with their dual function of trying to retain control over capital flows ${ }^{4}$ on the one hand and achieving a sound and safe financial infrastructure on the other; investors searching for profit opportunities; and managers trying to internationalize the cost of capital while maintaining control. The process of integration will be discussed below in terms of the complex interplay between these groups.

The paper presents a regional study of routes to equity market integration. The focus is on the Nordic region - Denmark, Finland, Norway and Sweden. ${ }^{5}$ In view of the role played by politicians in traditional welfare states such as these, this choice can provide a chart of all the dimensions of the integration process. The region can be said to have the highest total tax burden in global terms, which also means that politicians influence a greater proportion of the expenditures drawn from GDP. Further, since the region is singularly free from intraregional barriers and enjoys a high degree of transparency, it is possible to concentrate on differences in the transformation of the equity markets of the different countries without having to control for differences in language, accounting principles or disclosure norms.

The paper is organized as follows. Section 2 provides a brief description of the 
structure of the Nordic equity markets and the role they play in supplying companies with risk capital. Section 3 offers an analysis of attempts by politicians/regulators to influence the magnitude and scope of cross-border equity activities. Section 4 addresses such institutional and regulatory changes in domestic equity markets as are relevant to equity market integration. Section 5 analyses corporate efforts to eliminate cross-border information asymmetries by way of foreign listing and foreign capital market activities. Section 6 emphasizes defence against take-overs as a source of equity market segmentation. The main findings are then summarized in Section 7.

\section{Nordic equity markets - their role as suppliers of risk capital}

The embryos of the present Nordic national equity markets all go back a long way. They started as informal market places that were later augmented by extensive regulations. The Danish Stock Exchange - or, to be precise, the Copenhagen Stock Exchange - can be traced back to the end of the 17th century. In the 19th century, however, it became more tightly organized, and in 1808 it became one of the first markets in the world to regulate trade and brokerage conditions. The first modern law applying to the Stock Exchange appeared in 1919 and in 1921 a stock exchange index was introduced. The Finnish Stock Exchange goes back to the 19th century and the "Russian" period. It was initially based on self-regulation and gentlemen's agreements. In 1923 a stock exchange index was introduced. The Helsinki Stock Exchange has gradually come to be the predominant Finnish market place. The first signs of a Norwegian Stock Exchange can be traced back to the 18th century. In 1921 a stock exchange index was introduced. However, the 1931 Stock Exchange Regulation (Börsloven) can be regarded as the start of a market of the kind we see today. Following two mergers at the beginning of the 1990s, the Oslo Stock Exchange became the single Norwegian market place. The Swedish Stock Exchange - or, more precisely the Stockholm Stock Exchange dates back to February 1863 . The first regulation of stock market activities on the Exchange occurred in January 1868. A stock market of the type that we see today was constituted in 1901, the same year that a stock exchange index was introduced.

At the end of the 20th century the market capitalization of the individual Nordic equity markets is small in global terms. The market value of domestic companies traded on the Swedish market (the Stockholm Stock Exchange), which is the 
largest Nordic market, amounts to around 3 percent of the market value of shares traded on the New York Stock Exchange (NYSE). The market value of the Danish, Finnish and Norwegian markets together is less than that of the Swedish equity market. The low figures for turnover velocity in the 1970s and 1980s on all the Nordic markets reflect the largely successful efforts by regulators and policymakers to keep markets in a shape best suited to their own purposes.

The importance of the Nordic equity markets as suppliers of risk capital has varied considerably over time. After a period of low activity the volume of equity issues began to grow in the mid-1980s. Oxelheim et al. (1998) provided a historical perspective on the relative size of that increase, using Swedish data. Except for the booming interest in new issues in the period immediately preceding the crash of 1929 , there is in real terms nothing similar to the high issuing activity of 1985-92 in the whole of the rest of the 1915-92 period. The entire period can be divided into three sub-periods in terms of the relative importance of stock markets as suppliers of new capital: 1915-1929 (high), 1930-1979 (low) and 1980-1992 (high). Although the measure for the last period is far below that of the first, it still indicates a significant increase relative to the middle period, which was characterized by heavy regulation.

For all the Nordic countries there is support for a further division of the 19801992 into two parts, 1980-85 and 1986-92. The data indicates a revitalization of the individual Nordic equity markets in the second period. After a peak in 1993-94 the issuing patterns changed. In Sweden, for instance, from 1994 to 1998 the total amount of public offerings, directed cash issues and new issues with preferential rights for existing shareholders fell from SEK 41799 mill. to SEK 7779 mill. The greater use of directed non-cash issues by listed companies in connection with the acquisition of large blocks of shares in other companies, mitigated the dramatic fall and signified a new issuing trend. A similar trend also appeared on the other Nordic equity markets.

Few econometric studies have been published on the link between the Nordic and the "global" equity market. After studying Granger causality and using monthly prices for the stock indices, Mathur and Subrahmanyam (1990) concluded that in the period 1974-85 the four Nordic markets were less than fully integrated. Liljeblom, Löflund and Krokfors (1997) used monthly stock returns for the two sub-periods 1974-86 and 1987-93 and reported significant increases in stock market co-movement between the two. 


\section{Restrictions on cross-border equity activities}

The Second World War was followed by a period when policy-makers believed the best way to heal the economic wounds of the war was to impose various forms of regulation on the financial markets. In this way they did their best to create cheap domestic financing in order to boost economic recovery.

For long periods at a time regulators and policy-makers wielded great influence over national Nordic equity markets. Their objectives were different at different times. The regulatory devices can be classified as external or internal. External regulations include such things as capital controls and exchange rate regulations, and they involve national control over cross-border activities with a view of underpinning the efficiency of many internal regulations. These last, which will be discussed in Section 4, include regulations controlling the supply of products/services, the participation of financial institutions in domestic markets, and the activities of individual households, non-financial companies and local governments, etc. The internal devices also comprise rules governing tax liability.

For long periods the regulatory apparatus applying to the cross-border equity transactions of the Nordic countries was extremely restrictive. Cross-border capital flows were controlled by the respective governments for most of the postwar period. Before the Second World War, a few Nordic companies at least were traded on foreign stock markets. They included the Danish companies Unibank, GN Store Nord and ÖK Holding; Norsk Hydro from Norway; the Swedish Alfa Laval, Electrolux, SKF and Swedish Match, but no Finnish companies. On the occasion of their introduction abroad, these companies also issued new equity directed toward foreign investors. This situation came to an abrupt halt at the time of the stock market crash of 1929. The depression following the crash meant that the demand for new capital was very low, and by the time demand might have been expected to pick up, the outbreak of Second World War triggered extensive capital controls.

In Sweden, for instance, the 1939 capital controls made it illegal for Swedish securities to be sold to foreigners, or for Swedes to buy foreign securities. There were exceptions, however. Swedish securities in foreign hands and foreign securities in Swedish hands at the time of the institution of the controls in 
February 1939 could be traded. This gave the seller a "switch right", i.e. the right to buy a foreign security. The switch rights themselves were also tradable. During the 1970s the capital controls on security trading began to let up slightly: in 1974 Volvo was granted permission to export shares of common stock abroad; and between 1975 and 1981 half a dozen other Swedish companies were granted similar export permits (see Stjernborg 1987). However, no companies issued new equity abroad. Instead they created markets with existing stocks on foreign exchanges. Share exports increased after 1982, and Swedish companies were now being granted permission to export shares on a routine basis (provided they were listed on the Stockholm Stock Exchange). Further liberalization came in 1986 when the Swedish Central Bank announced that permission to export shares would "normally" be granted to all publicly listed stocks, OTC-stocks, and in certain circumstances to other stocks as well. In 1989 the last remnants of this regulation were abandoned. Norway and Finland subscribed to systems similar to the Swedish "switch" system.

As can be seen in Figure 1, the real take-off for the export of shares occurred around the middle of the 1990s. The figure provides us with an indicator similar to

Figure 1 Gross exports of Nordic shares as a percentage of market capitalization Export (capital flow) as compared to year-end market capitalization.

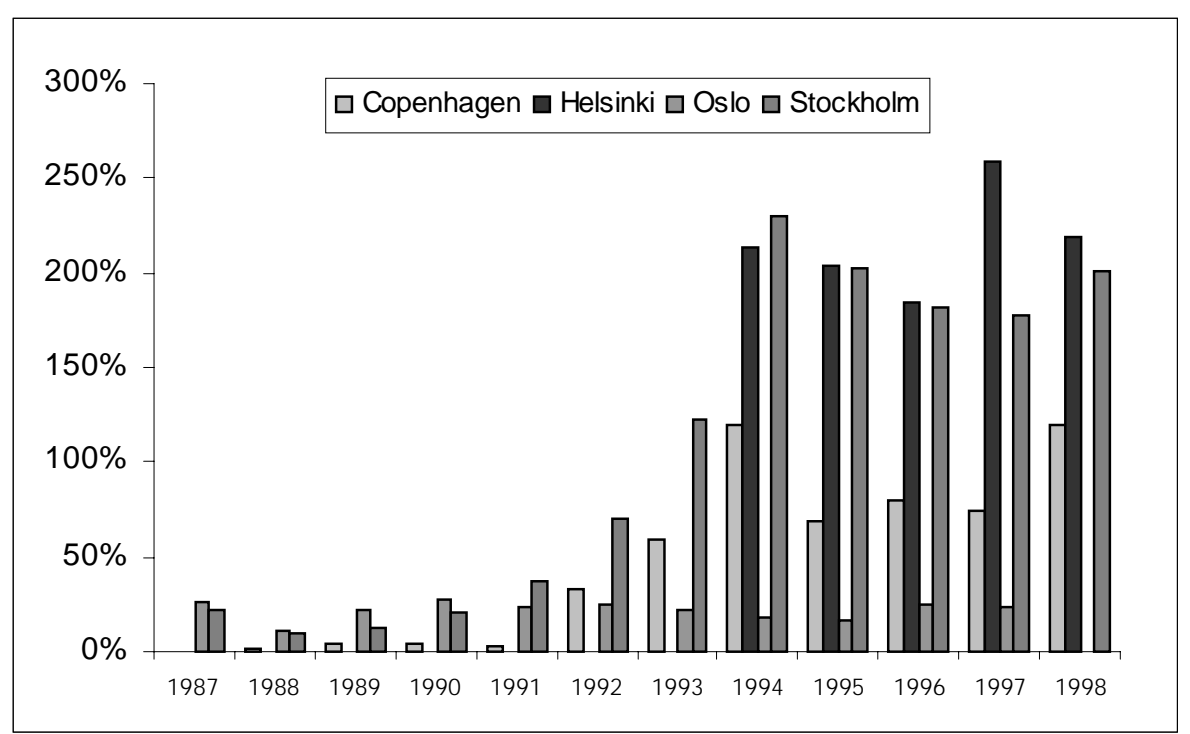

Sources: Stock Exchanges of the various Nordic countries, Data bases; Central Banks of the various Nordic countries, Data bases; Finnish Central Securities Depository, Data base; Central Statistical Bureau of Norway, Statistics Norway. The period 1993 - 1997 includes no Norwegian financial companies. 
the measure of openness to international trade that is often used in the context of economic integration. Bigger cross-border capital flows at that time indicate growing equity market integration, coinciding with the implementation of the European Economic Area treaty in 1994.

Table 1 provides a framework for a further analysis of Nordic equity market integration based on the timing of the Nordic regulation/deregulation of crossborder equity activities. Many of the issues included were regulated by the exchange controls, but many were subject to changes in practice by the Central Banks of the different countries and to changes in other legal arrangements such as Concessions Acts and Acquisition Laws. It should be stressed that collecting the data was a complicated task. Recent history is obviously of minor interest in a deregulating world, which has meant that the bulk of data used here has been generated by interviews rather than by the simple gathering of secondary data.

The dates under "Introduced" in Table 1 indicate when the current period of regulation started. The identification of this date as well as most of the dates given in the table should be approached with caution. In most cases the year given is the year in which exchange controls were introduced. Subsequent to that year the regulation/deregulation pendulum may have swung back and forth a couple of times before a steady route towards deregulation was embarked upon. The dates under "eased" are key dates on the way to a deregulated market. However, it is not always possible to identify an individual year in which deregulation occurred. Instead there was generally a period during which policy-makers or central bankers started to show a more relaxed attitude towards cross-border equity activities. In such cases a period rather than an individual year is given in the table. Finally, the dates under "abolished" indicate the year when restrictions on the right to carry out a particular activity were abolished. But even after that date there may still be some restrictions on the way the activity is conducted. A frequent example of this was that the acquisition of foreign shares by domestic investors had be done through a domestic broker and the shares had to be kept in domestic custody. 
Table 1 Regulations applying to Nordic cross-border equity activities

\begin{tabular}{|c|c|c|c|c|c|c|}
\hline & \multicolumn{6}{|c|}{ Dates of institutional changes } \\
\hline & \multicolumn{3}{|c|}{ Denmark } & \multicolumn{3}{|c|}{ Finland } \\
\hline & Introduced & Eased & Abolished & Introduced & Eased & Abolished \\
\hline Listings and issues & & & & & & \\
\hline $\begin{array}{l}\text { Restrictions on } \\
\text { listings abroad }\end{array}$ & - & - & - & - & - & - \\
\hline $\begin{array}{l}\text { Restrictions on } \\
\text { listing of foreign } \\
\text { companies on the } \\
\text { domestic equity } \\
\text { market }\end{array}$ & 一 & 一 & 一 & Sept 1941 & June 1985 & Jan 1994 \\
\hline $\begin{array}{l}\text { Restrictions on } \\
\text { equity issues } \\
\text { directed to foreign } \\
\text { investors }\end{array}$ & 1931 & Dec 1972 & Jan 1984 & Sept 1941 & $\begin{array}{c}\text { During the } \\
1980 \mathrm{~s}\end{array}$ & Feb 1990 \\
\hline $\begin{array}{l}\text { Restrictions on } \\
\text { foreign equity } \\
\text { issues on the } \\
\text { domestic market }\end{array}$ & 1931 & Dec 1972 & Oct 1988 & Sept 1941 & Apr 1985 & Feb 1990 \\
\hline Investments & & & & & & \\
\hline $\begin{array}{l}\text { Restrictions on the } \\
\text { acquisitions of } \\
\text { foreign shares by } \\
\text { domestic investors: } \\
\text { - listed shares } \\
\text { - non-listed shares }\end{array}$ & $\begin{array}{l}1931 \\
1932\end{array}$ & $\begin{array}{c}- \\
\text { June } 1985\end{array}$ & $\begin{array}{l}\text { Jan } 1984 \\
\text { July } 1986\end{array}$ & $\begin{array}{l}\text { Sept } 1941 \\
\text { Sept } 1941\end{array}$ & $\begin{array}{c}\text { Jan 1986, } \\
\text { 1987, } 1988 \\
-\end{array}$ & $\begin{array}{l}\text { Sept } 1989 \text {, } \\
\text { July } 1990^{1} \\
\text { Sept } 1989, \\
\text { July } 1990^{1}\end{array}$ \\
\hline $\begin{array}{l}\text { Restrictions on the } \\
\text { acquisitions of } \\
\text { domestic shares by } \\
\text { foreign investors: } \\
\text { - listed shares }\end{array}$ & 1932 & - & Dec 1972 & July 1939 & $\begin{array}{c}\text { May } 1959 \\
\text { Jan } 1973,\end{array}$ & Jan 1993 \\
\hline $\begin{array}{c}\text { - non-listed shares } \\
\text { - shares of national } \\
\text { strategic value } \\
\text { (e.g. defense) }\end{array}$ & 1932 & 1990 & May 1983 & July 1939 & Jan 1993 & Jan 1993 \\
\hline
\end{tabular}

${ }^{1}$ Abolished for companies in September 1989, for private individuals in July 1990. 


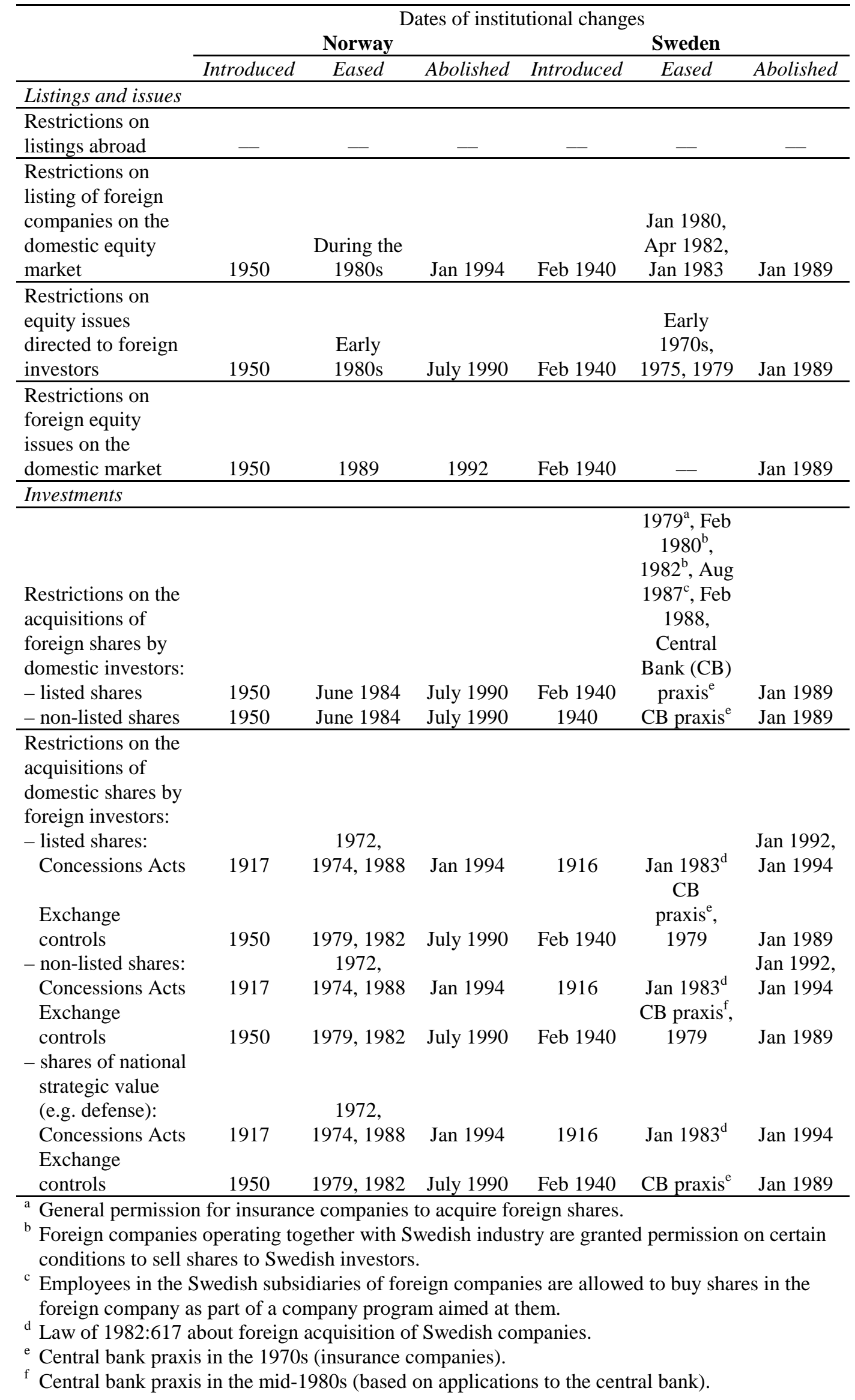


Table 1 reveals Danish regulators to have been very liberal in their attitude towards cross-border equity activities. Their regulations were few, and relaxation came early. The other Nordic equity markets were heavily regulated until the mid1980s. During the early 1980s, however, there was a gradual liberalization expressed not in explicit deregulation but in a more relaxed attitude to authorization on the part of the central bankers. In the first few years of the 1990s the Nordic markets were all integrated with the global market place in a regulatory perspective.

The changed attitude of the policy-makers and regulators was to some extent an acknowledgement that existing regulations had become eroded and inefficient. But it was also an expression of a change in the philosophy underlying national economic policies in the 1980s. There was a growing recognition that excessive controls are not compatible with efficient resource allocation or with solid and balanced economic growth. It was becoming increasingly evident that controls discourage financial savings, distort investment decisions and make for ineffective intermediation between savers and investors.

In Finland, Norway and Sweden the exchange regulations normally referred to the maximum amount of particular shares that could be traded across borders, while the Concession Acts dictated the maximum limits to the foreign ownership of individual companies. The limits differed across countries and industries. In the 1980s an upper limit was often set at 20 percent. Restricted shares existed in all the Nordic countries. Foreign investors could only buy non-restricted shares. Further, it was open to the firm to reduce the proportion of shares available to foreigners even more, by referring to a provision in the Articles of Association. A number of companies offered foreign investors no opportunities at all. For instance, in 1988 non-restricted shares in listed Finnish industrial companies amounted to no more than around 10 percent and in listed trade and transportation companies to about 3 percent. A restriction that remained in most of the Nordic countries even many years after capital controls had been lifted was the restriction on the acquisition by foreigners of shares of national strategic value, for instance shares in the defense industry or in public utilities. 
Figure 2 Share of foreign ownership in Nordic listed companies 1987-1999

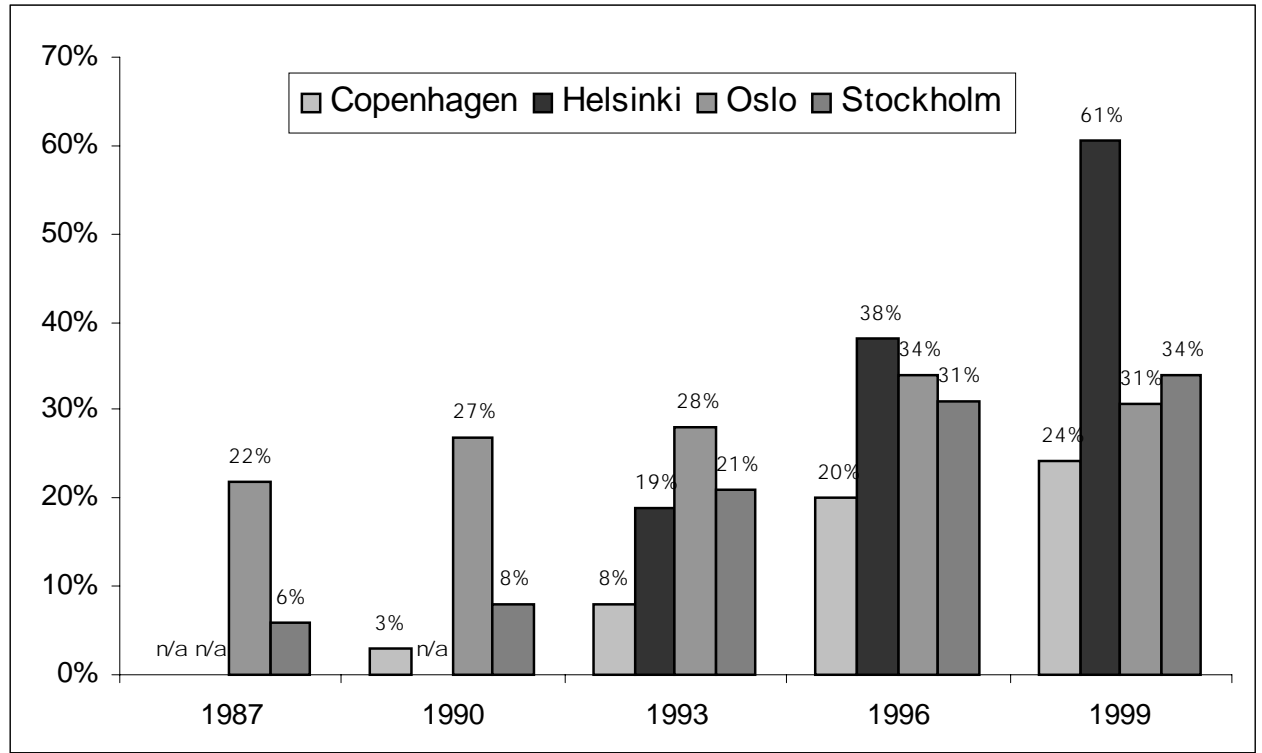

Source: Copenhagen Stock Exchange, The Nordic Securities Market Quarterly Statistics 2/95, Supplement; Copenhagen Stock Exchange, Database; Helsinki Stock Exchange, Database; Oslo Stock Exchange, Database; Stockholm Stock Exchange, Database.

The shifting attitudes among politicians towards foreign ownership and the corresponding response from foreign investors are captured in Figure 2. At the end of the 1980s the share of foreign ownership was highest in Norway at 27 percent (up from 15 percent in 1985), and the lowest in Denmark at 3 percent. A single firm, Novo Nordisk, accounted for about half the Danish figure. In January 1994 the European Economic Area Treaty brought all the Nordic equity markets into the "European" equity market. This meant an end to the system of restricted shares. At the end of the 1990s about 1/3 of the shares in Norwegian and Swedish firms were owned by foreigners, as compared to almost $2 / 3$ in Finnish firms. Despite the liberal attitude to foreign ownership shown by the Danish authorities earlier than by their counterparts in the other Nordic countries, the Danish figure is considerably lower.

The policy-makers' increasingly positive attitude towards equity meant that even foreign companies were willing to list their shares on the Nordic stock exchanges. Table 2 shows that the Danish, Norwegian and Swedish markets experienced a substantial increase in their foreign listings from 1987 onwards. A listing on these comparatively small Nordic stock exchanges was often undertaken in order to bridge an information gap, to make it easier for subsidiary employees who had received equity interest through a company program to follow the development of 
their shares.

Table 2 Number of companies listed on the Nordic stock exchanges 1980-1999

\begin{tabular}{ccccccccc}
\hline & \multicolumn{2}{c}{ Denmark } & \multicolumn{2}{c}{ Finland } & \multicolumn{2}{c}{ Norway } & \multicolumn{2}{c}{ Sweden } \\
Year end & Domestic & Foreign & Domestic & Foreign & Domestic & Foreign & Domestic & Foreign \\
\hline 1980 & 218 & 4 & 50 & 0 & 117 & 7 & 103 & 0 \\
1981 & 210 & 4 & 50 & 0 & 109 & 6 & 130 & 0 \\
1982 & 206 & 4 & 49 & 0 & 112 & 6 & 138 & 1 \\
1983 & 206 & 4 & 48 & 0 & 113 & 6 & 145 & 5 \\
1984 & 231 & 5 & 52 & 0 & 140 & 8 & 159 & 6 \\
1985 & 243 & 6 & 50 & 1 & 156 & 7 & 164 & 7 \\
1986 & 274 & 7 & 49 & 3 & 147 & 7 & 226 & 7 \\
1987 & 269 & 9 & 49 & 3 & 149 & 10 & 223 & 7 \\
1988 & 260 & 7 & 66 & 3 & 128 & 6 & 217 & 9 \\
1989 & 257 & 8 & 78 & 4 & 122 & 7 & 256 & 10 \\
1990 & 258 & 10 & 73 & 4 & 112 & 9 & 243 & 15 \\
1991 & 261 & 11 & 63 & 2 & 107 & 9 & 217 & 13 \\
1992 & 257 & 11 & 62 & 1 & 119 & 8 & 192 & 13 \\
1993 & 246 & 11 & 58 & 0 & 124 & 11 & 195 & 10 \\
1994 & 243 & 10 & 65 & 0 & 132 & 14 & 217 & 11 \\
1995 & 242 & 10 & 73 & 1 & 151 & 14 & 212 & 11 \\
1996 & 237 & 12 & 71 & 2 & 158 & 14 & 229 & 12 \\
1997 & 249 & 12 & 80 & 2 & 196 & 21 & 245 & 16 \\
1998 & 247 & 12 & 130 & 2 & 213 & 22 & 258 & 18 \\
$1999 *$ & 234 & 10 & 150 & 3 & 196 & 20 & 281 & 23 \\
\hline$*$ & End & of November & & & & & & \\
a A-list $1980-1985$ and total list $1986-1999$ & & & & \\
\end{tabular}

In this section we have seen that, with respect to the prerequisites for equity market integration, most barriers to cross-border equity activities with Nordic markets had been relaxed by 1999 . What remained were restrictions imposed for tax reasons on the way these activities are to be conducted. The lifting of restrictions on cross-border activities has boosted the interest of foreign investors in Nordic companies as well as arousing an interest among foreign companies to list on the various Nordic equity markets. Altogether this indicates that perfect equity market integration - from a capital-flow point of view - could be expected to prevail. The complex interplay between Nordic politicians/regulators, corporations and foreign investors also seems likely in a general way to have contributed to the bridging of potential cross-border information gaps, thus adding to an all-encompassing form of equity market integration. 


\section{Internal regulations and institutional changes}

The internal regulatory bodies in the Nordic countries deal with the regulation of the operations of the financial system and the tax legislation relating to capital gains tax, wealth tax, tax on dividends and tax on traded securities. One important way of promoting government control over the development of equity market integration has been by influencing debt/equity ratios. In addition to tax-related policy changes, three ways of favoring debt financing can usually be distinguished: by exerting control over the development of stock markets, over the extent to which financial and non-financial companies are owned by the government, and over the granting of financial assistance to companies through a variety of subsidized credit facilities.

However, the Nordic authorities have typically influenced the balance between the various sources of capital through their tax policies. For most of the post-war period equity financing has been more expensive for companies than credit financing. To be able to pay a dividend in a sustainable way a company must show a profit on which tax has to be paid, whereas the costs of credit financing are taxdeductible. Since the countries in the Nordic region can all be classified as "political economies" with very high tax burdens, it is easy to understand why the interest tax shield has been very attractive for long periods at a time. At the beginning of the 1980s the debt ratios in two of the Nordic countries - Finland and Norway - were close to the Japanese level, while in the other two countries the levels were slightly above the European average. By the end of the 1990s, however, the ratios of all the Nordic countries had converged to the "OECD" average.

The equity euphoria at the end of the 1980s led some governments to impose new taxes on equity. In 1988 a 1 percent turnover tax on equity trading was introduced in Norway. The tax was very short-lived and was lifted at the end of the year. In the other Nordic countries similar efforts persisted longer. In Denmark the authorities in certain circumstances charged a fee of 1 percent of the market value of traded shares. Finland imposed a 1 percent tax on the amount traded on the stock exchange and 1.6 percent on the amount traded outside it. In addition there was also a stock exchange fee of 0.05 percent (maximum FIM 500). In Sweden both buyers and sellers had to pay a tax of 0.5 percent of the amount traded.

During the 1980s Nordic policy-makers gradually moved towards eliminating 
incentives that favored loans rather than equity. However, as was noted in OECD (1991), at the beginning of the 1990s all the Nordic countries showed tax wedges when company and personal income taxes were both taken into account. All these wedges were above the EU average, and in all cases except Sweden above the OECD average as well. The double taxation of dividends was reduced in all the Nordic countries in the first half of the 1990s: in Denmark in 1991, in Finland in 1990, in Norway in 1991 and in Sweden in 1994. In the mid-1990s, however, with a new government installed, full double taxation was reintroduced in Sweden. This happened at a time when the global tax level was falling. On a list of total (corporate and shareholder) tax rates on dividends in 1998, Sweden and Denmark belonged to the top OECD group with 49.6 percent and 50.5-60.4 percent respectively, while Finland and Norway, both at 28 percent, appeared near the bottom of that list (IBFD, 1998). A closer look reveals that corporate tax rates on dividends were 28 percent in Finland, Norway, and Sweden and 34 percent in Denmark. Shareholders' tax rates on dividends were nil in Finland and Norway, 25-58 percent in Denmark, and 30 percent in Sweden. In terms of wealth tax, too, Sweden belongs to the top OECD group, while on this count Denmark has moved in the direction of the "benchmark" rate and since 1997 has abandoned this source of tax income. The wealth tax in Norway almost reaches the Swedish level while the Finnish rate is slightly lower. Capital gains taxes in Denmark (0-58 percent), Finland (28 percent), Norway ( $0-28$ percent) and Sweden (30 percent) are all high in an OECD perspective.

In addition to the tax laws and the restriction on financial operations there are internal measures of a corporate governance kind that are important to the functioning of equity markets. As we will see in a later section, there are restrictions on companies buying back their own shares, that is to say trading in their own shares as opposed to making a redemption, and it is obligatory to publish major increases in the stakes in a company.

The EU proposal of "one share-one vote" is also being currently debated. At the end of the 1990s shares carrying different voting power exist in all the Nordic countries. In Finland the authorities have set a maximum spread from 20 votes (Ashares) to one vote (B-shares). Companies cover the whole spectrum. In Denmark and Sweden most shares traded on the stock exchanges carry from 10 votes for Ashares to one vote for B-shares. B-shares in Norway sometimes have no voting rights at all. 
A number of other laws are in force regarding internal regulations, with the predominant aim of guaranteeing the safety and soundness of the financial infrastructure: stock exchange laws, securities laws and laws about supervision. To avoid conflict and to eliminate arbitrage opportunities emanating from different supervisory subsystems, a merger of the various national supervisory institutions into one for each country was carried out in the Nordic countries at the beginning of the 1990s (Oxelheim, 1996).

In this section we have seen that, with respect to the prerequisites for equity market integration, Denmark and Sweden, with their more or less full double taxation of dividends, deviated at the end of the 1990s from the other Nordic countries and from the global trend. In addition, as political economies the Nordic countries all exhibit wedges relative to the benchmark tax rates of the "global" market also when it comes to taxes on capital gains and, except in the case of Denmark, to taxes of wealth. As well as these residual causes of equity market segmentation, there are also inefficiencies generated by the complex interplay between politicians/regulators and managers. These causes of segmentation, which will be addressed in Sections 5-6 in a managerial perspective, are largely due to differences in corporate governance systems. One such cause arises from the gap between Nordic disclosure norms and the requirements formulated by the Security Exchange Commission. Another cause connected with the same area lies in the lax attitudes of Nordic politicians to the dual voting system.

\section{Corporate efforts to bridge cross-border information gaps}

The corporate efforts to close cross-border information gaps and to internationalize the cost of capital can be combined in many different strategies, but two main ingredients do emerge: listing the company's shares on one or more foreign stock exchanges and/or directing equity issues to investors in one or more foreign countries. Modén and Oxelheim (1997) analyze the international equity issues by Swedish firms between 1981 and 1995 and show that the information factor (financial and commercial marketing) ranked highest among the reasons that lay behind these issues. Although the two main ingredients mentioned above are generally combined in the strategy chosen by the individual companies, I will discuss them separately below. 
In most companies the corporate strategies for bridging the information gap represent a gradual process. This is demonstrated in Figure 3. A company that wants to avoid a failure to raise capital on its target market can follow the long route shown on the left of the figure, gradually gaining experience and recognition. Novo, the first Nordic company to raise capital on the US market in the post-war period, and thus lacking any immediately relevant experience, followed the route in the middle of the figure. In the 1990s most large companies started with a listing on the target market or let listing and issue occur simultaneously, thus following the routes to the right in the figure. Further, most of these companies opted for more than one market, as evident by their choice of a euro-equity issue.

\subsection{Bridging cross-border information gaps by listing abroad}

In the 1980s Nordic firms became increasingly interested in cross-listing. Before 1980 no Finnish companies were listed abroad, while four Danish companies, one Norwegian and eleven Swedish companies were listed on international stock markets. The practice differed across countries. Danish companies were predominantly listed on one market only, whereas Swedish companies were typically listed in several market places. In the Nordic context, the Swedish companies Ericsson and Swedish Match were represented on the greatest number of exchanges. Of Ericsson's eleven markets, three were in Switzerland. Swedish Match was listed on ten exchanges, of which five were Swiss. Norsk Hydro, listed on eight markets - three of which were Swiss - came third in this respect. Common to all these Nordic companies was their considerable size, and all - with a few Danish exceptions - were manufacturing companies.

A large number of Nordic companies were listed on stock exchanges abroad during the period 1980-1999 (see Table 3). This occurred either with or without simultaneous equity issues. In recent years international cross-listing has occurred in special shares of the foreign firm (known as depositary receipts or DRs). American Depositary Receipts (ADRs) are the publicly traded security in the USA. Three levels of ADR exist depending on (1) whether they are traded on the over-the-counter market (level-one) or (2) are exchange-listed without raising new capital (level-two) or (3) the same but with such an issue (level-three). If a company is admitted for listing it must be able to support initial and continuation fees as well as the cost of meeting the disclosure requirements. 
Figure 3 Major corporate strategies for eliminating cross-border information asymmetries in internationalizing the cost of capital

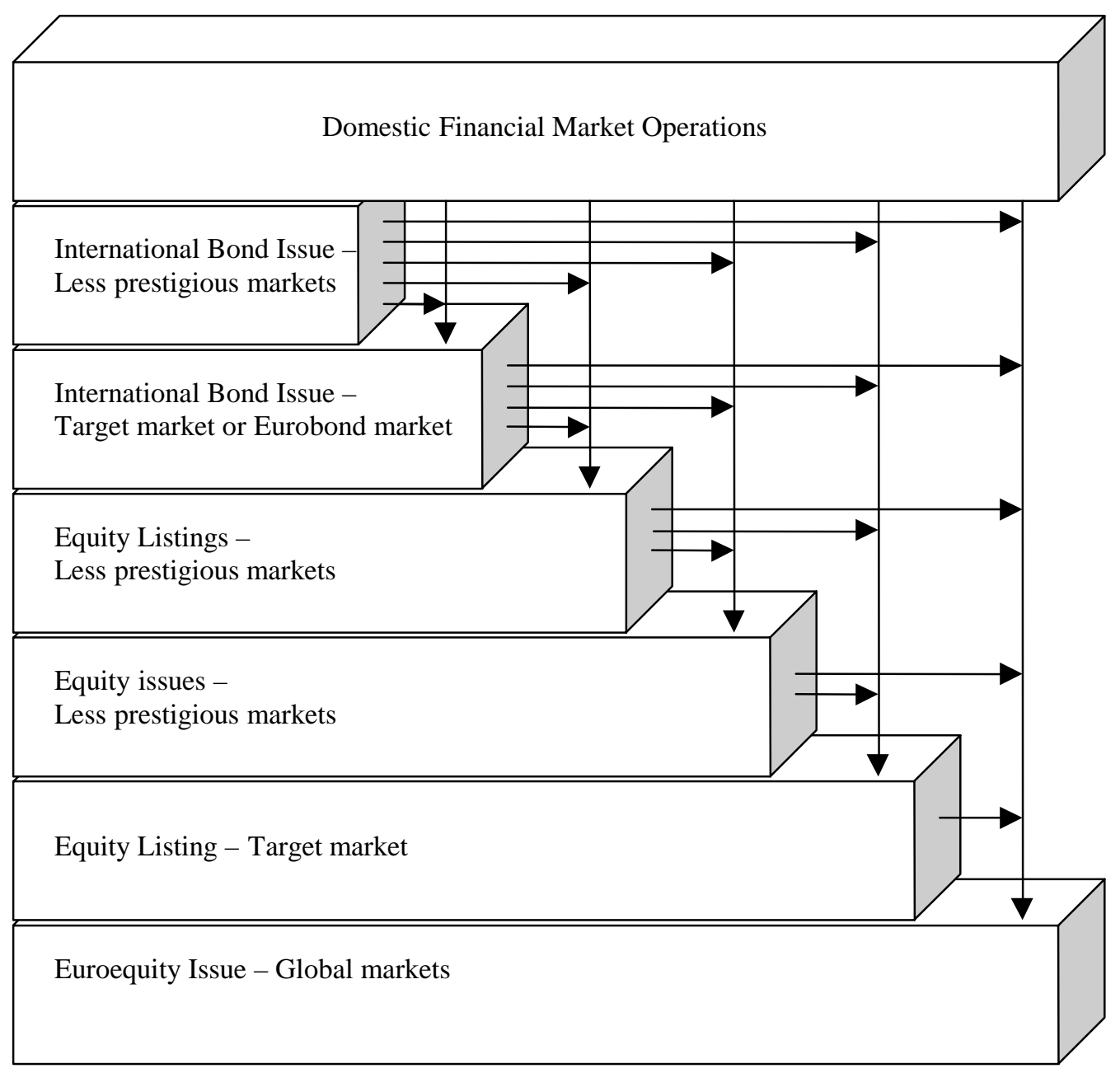

Interest in cross-listing peaked among Danish companies in the early 1990s. In 1999, the number of companies listed abroad had dropped to a few only. Listing in the UK or the US was the choice of these few.

Finnish companies started to list abroad at the beginning of the 1980s. In 1985 six companies were listed abroad, three of them in Stockholm. In 1985, in addition to Stockholm, Finnish companies opted for the London Stock Exchange (LSE). In 1991, ten companies were listed on the LSE and by 1999 the number had dropped to two. The reason for this may have been high cost, and the fact that the companies can be traded on the SEAQ International (Stock Exchange Automated Quotations System), once three market-makers are willing to back them. In 1999, 
the US market - together with the Swedish - was the most common choice for Finnish cross-listing.

When it comes to listing practice, Norway was ahead of the other Nordic countries in the 1980s in its corporate efforts at internationalization. From having one company listed abroad in 1980, the country had fourteen in 1991. All except one (Freia) were listed in the UK. In 1996 Norwegian companies were traded on the SEAQ International without listing on the LSE. By the mid-1990s the US markets had passed the LSE as the target markets for cross-listing.

Since the mid-1980s Swedish companies have maintained a fairly constant presence on the major stock exchanges. In the period 1981-1993 about half of their listings were accompanied by an issue (equivalent to level three). In the mid1980s some companies also started to show an interest in listing on the other Nordic stock exchanges. By the mid-1990s some Swedish companies were taking a new line and were listing on the NYSE (Astra and Scania).

The LSE has been the most popular market place for cross-listing in all the Nordic countries. In the later 1990s, however, the US markets Nasdaq and NYSE have been catching up. This shift in preference can be explained by a legal change that allows companies with dual shares to list, and by expectations about the market value created by a listing on the US exchanges. The US information requirements as formulated by the Security Exchange Commission are very demanding, which means a great leap forward in terms of bridging the cross-border information gap for such Nordic companies as can manage to meet them. At the end of the 1990s another conspicuous feature was that even quite small companies were daring to embark on cross-listing.

The widespread use of shareholder value analysis at the end of the 1990s may explain a de-listing practice that can be observed, for instance in presence of Swedish companies on the other Nordic stock exchanges. As was noted above, listing on many exchanges may be part of a learning process and a strategy for acquiring global recognition. But once this recognition has been earned, the greater focus on the cost of capital as part of the shareholder value analysis, and the high cost of supporting a multiple listing strategy, may motivate de-listing. 
TABLE 3 Listing of Nordic companies on different stock exchanges abroad, 1980-1999

\begin{tabular}{|c|c|c|c|c|c|c|c|c|c|c|c|c|c|c|c|c|c|c|}
\hline \multirow[b]{2}{*}{$\begin{array}{c}\text { Companies } \\
\text { from }\end{array}$} & \multicolumn{4}{|c|}{ Nordic markets } & \multicolumn{5}{|c|}{ Other European markets } & \multicolumn{9}{|c|}{ Non-European market } \\
\hline & Year & Denmark & Finland & Norway & Sweden & Belgium & France & Germany & Italy & $\begin{array}{c}\text { Nether- } \\
\text { lands }\end{array}$ & $\begin{array}{c}\text { Switzer- } \\
\text { land }\end{array}$ & UK & $\begin{array}{c}\text { US } \\
\text { nasdaq }\end{array}$ & NYSE & $\begin{array}{c}\begin{array}{c}\text { US pink } \\
\text { sheet }\end{array} \\
\end{array}$ & Japan & $\begin{array}{c}\begin{array}{c}\text { Singa- } \\
\text { pore }\end{array} \\
\end{array}$ & Bermuda \\
\hline \multirow[t]{5}{*}{ Denmark } & 1980 & - & 0 & 0 & 0 & 0 & 2 & 0 & 0 & 1 & 0 & 2 & 0 & 0 & 0 & 0 & 0 & 0 \\
\hline & 1985 & - & 0 & 0 & 1 & 0 & 2 & 0 & 0 & 1 & 0 & 2 & 0 & 1 & 0 & 0 & 0 & 0 \\
\hline & 1991 & - & 0 & 1 & 0 & 0 & 2 & 5 & 0 & 1 & 2 & 6 & 0 & 1 & 0 & 0 & 0 & 0 \\
\hline & 1996 & - & 0 & 0 & 0 & 0 & 0 & 1 & 0 & 0 & 2 & 5 & 0 & 3 & 0 & 0 & 0 & 0 \\
\hline & 1999 & - & 1 & 0 & 1 & 0 & 0 & 0 & 0 & 0 & 0 & 3 & 0 & 2 & 0 & 0 & 0 & 0 \\
\hline \multirow[t]{5}{*}{ Finland } & 1980 & 0 & - & 0 & 0 & 0 & 0 & 0 & 0 & 0 & 0 & 0 & 0 & 0 & 0 & 0 & 0 & 0 \\
\hline & 1985 & 0 & - & 0 & 3 & 0 & 0 & 0 & 0 & 0 & 0 & 3 & 1 & 0 & 0 & 0 & 0 & 0 \\
\hline & 1991 & 0 & - & 0 & 2 & 0 & 1 & 1 & 0 & 0 & 0 & 10 & 1 & 2 & 0 & 0 & 0 & 0 \\
\hline & 1996 & 0 & - & 0 & 1 & 0 & 1 & 1 & 0 & 0 & 0 & 2 & 4 & 3 & 0 & 0 & 0 & 0 \\
\hline & 1999 & 1 & - & 0 & 5 & 0 & 1 & 1 & 0 & 0 & 0 & 2 & 2 & 3 & 0 & 0 & 0 & 0 \\
\hline \multirow[t]{5}{*}{ Norway } & 1980 & 0 & 0 & - & 0 & 0 & 1 & 1 & 0 & 0 & 1 & 1 & 0 & 0 & 0 & 0 & 0 & 0 \\
\hline & 1985 & 0 & 0 & - & 2 & 0 & 1 & 3 & 0 & 0 & 1 & 3 & 1 & 0 & 0 & 0 & 0 & 0 \\
\hline & 1991 & 1 & 0 & - & 1 & 0 & 1 & 4 & 1 & 1 & 1 & 13 & 1 & 1 & 0 & 0 & 0 & 0 \\
\hline & 1996 & 2 & 0 & - & 2 & 0 & 1 & 2 & 0 & 1 & 1 & 5 & 4 & 6 & 0 & 0 & 0 & 0 \\
\hline & 1999 & 2 & 0 & - & 2 & 0 & 1 & 3 & 0 & 1 & 1 & 3 & 3 & 5 & 0 & 0 & 1 & 1 \\
\hline \multirow[t]{5}{*}{ Sweden } & 1980 & 0 & 0 & 2 & - & 2 & 3 & 3 & 0 & 2 & 5 & 10 & 1 & 0 & 0 & 0 & 0 & 0 \\
\hline & 1985 & 2 & 1 & 4 & - & 2 & 5 & 3 & 0 & 2 & 5 & 18 & 6 & 0 & 4 & 0 & 0 & 0 \\
\hline & 1991 & 6 & 3 & 4 & - & 1 & 5 & 6 & 0 & 1 & 6 & 15 & 7 & 0 & 3 & 2 & 0 & 0 \\
\hline & 1996 & 4 & 0 & 2 & - & 1 & 5 & 7 & 0 & 0 & 5 & 15 & 8 & 2 & 4 & 2 & 0 & 0 \\
\hline & 1999 & 3 & 0 & 0 & - & 1 & 3 & 4 & 0 & 0 & 4 & 15 & 8 & 1 & 5 & 1 & 0 & 0 \\
\hline
\end{tabular}


5.2 Closing cross-border information gaps by raising equity on foreign markets

Table 4 provides an idea of the incidence of equity issues directed abroad by Nordic companies. It shows the total volume of such issues, as well as their percentage of the total issues of companies in the individual countries. For the first four decades of the post-war period the Nordic equity markets were segmented markets with low liquidity. Hence, there were strong arguments for companies in the Nordic countries to opt for internationalizing their cost of capital. Modén and Oxelheim (1997) show that cross-listing is not enough; a simultaneous issue is necessary if the company is to signal its strong commitment. To secure this and to avoid eroding the wealth of existing shareholders (if the issue were placed on thin and inefficient markets), once they got started Nordic companies opted primarily for the US and UK markets.

It should be noted, and taken as a word of warning, that for a number of reasons an analysis of the relative importance of equity issues abroad is associated with severe data problems. In a country like Denmark the data gathering boils down to a search for mention of such issues in annual reports. The Danish authorities show no particular interest in registering cross-border issues. Some aggregated data can be found for the other countries. However, the mode of reporting differs from country to country, which has meant looking for ways of making the data compatible.

Moreover, it has not been possible to make any distinction between public issues and issues directed to one or a couple of investors. Convertible bond issues are excluded. A further registration problem concerns the emergence of euro-equity issues, and the fact that directed issues are becoming increasingly blurred and harder to identify. One reason is that the foreign investors' rate-of-return requirement and savings can be obtained in the home market. Hence, the opening up of Nordic national equity markets to foreign investors should to some extent have reduced the need for issues abroad directed to that category for purely capital-market reasons. Table 4 captures the change of issuing behavior by including from 1996 onwards also non-cash directed issues. The entry of foreign investors operates as a catalyst and a "pull" mechanism in the process of making the national equity market part of the "global" equity market. In the case of perfect equity market integration, directed issues with a view to internationalizing the cost of capital should eventually amount to zero. However, other reasons for undertaking equity issues abroad, such as product marketing, remain. 
Table 4 Amounts of capital raised from new equity issues directed abroad

\begin{tabular}{|c|c|c|c|c|c|c|c|c|}
\hline & \multicolumn{2}{|c|}{ Denmark } & \multicolumn{2}{|c|}{ Finland } & \multicolumn{2}{|c|}{ Norway } & \multicolumn{2}{|c|}{ Sweden } \\
\hline & $\begin{array}{l}\text { Raised by } \\
\text { Danish } \\
\text { firms } \\
\text { abroad } \\
\text { (million } \\
\text { DKK) }\end{array}$ & $\begin{array}{c}\% \\
\text { of total } \\
\text { capital } \\
\text { raised } \\
\text { from new } \\
\text { equity } \\
\text { issues }\end{array}$ & $\begin{array}{l}\text { Raised by } \\
\text { Finnish } \\
\text { firms } \\
\text { abroad } \\
\text { (million } \\
\text { FIM) }\end{array}$ & $\begin{array}{c}\% \\
\text { of total } \\
\text { capital } \\
\text { raised } \\
\text { from new } \\
\text { equity } \\
\text { issues }\end{array}$ & $\begin{array}{l}\text { Raised by } \\
\text { Norwe- } \\
\text { gian } \\
\text { firms } \\
\text { abroad } \\
\text { (million } \\
\text { NOK) }\end{array}$ & $\begin{array}{c}\% \\
\text { of total } \\
\text { capital } \\
\text { raised } \\
\text { from new } \\
\text { equity } \\
\text { issues }\end{array}$ & $\begin{array}{l}\text { Raised by } \\
\text { Swedish } \\
\text { firms } \\
\text { abroad } \\
\text { (million } \\
\text { SEK) }\end{array}$ & $\begin{array}{c}\% \\
\text { of total } \\
\text { capital } \\
\text { raised } \\
\text { from new } \\
\text { equity } \\
\text { issues }\end{array}$ \\
\hline 1981 & 450 & 78.9 & na & na & 0 & 0 & 798 & 28.2 \\
\hline 1982 & 0 & 0 & 34 & 3.7 & 20 & 1.9 & 150 & 6.5 \\
\hline 1983 & 966 & 33.7 & 370 & 29.6 & 217 & 7.6 & 3904 & 40.8 \\
\hline 1984 & 0 & 0 & 635 & 21.8 & 646 & 21.4 & 371 & 5.6 \\
\hline 1985 & 115 & 2.5 & 182 & 13.1 & 123 & 3.5 & 547 & 19.3 \\
\hline 1986 & 232 & 2.5 & 996 & 28.6 & 1027 & 32.5 & 2366 & 55.2 \\
\hline 1987 & 407 & 11.4 & 601 & 11.4 & 4 & 0.2 & 42 & 0.6 \\
\hline 1988 & 698 & 14.0 & 231 & 2.7 & 6 & 0.1 & 0 & 0 \\
\hline 1989 & 615 & 4.7 & 419 & 4.9 & 1924 & 26.4 & 250 & 3.0 \\
\hline 1990 & 237 & 3.5 & 499 & 29.7 & 2708 & 40.3 & 2441 & 24.6 \\
\hline 1991 & na & na & 5 & 0.1 & 650 & 22.3 & 0 & 0 \\
\hline 1992 & na & na & 0 & 0 & 458 & 8.1 & 710 & 17.1 \\
\hline 1993 & na & na & 4188 & 42.8 & na & na & 870 & 3.2 \\
\hline 1994 & na & na & 7701 & 69.8 & na & na & 194 & 0.5 \\
\hline 1995 & na & na & 2727 & 89.5 & na & na & 193 & 0.7 \\
\hline 1996 & 3438 & 52 & 4161 & 91 & 4188 & 68 & $16409(0)$ & $52(0)$ \\
\hline 1997 & 1761 & 50 & 7512 & 89 & 5621 & 75 & $20320(0)$ & $71(0)$ \\
\hline 1998 & 1566 & 38 & 9272 & 63 & 545 & 11 & $4127(421)$ & $48(14,4)$ \\
\hline
\end{tabular}

Source: Annual reports, 1981-1995; National Stock Markets, Database 1981-1995. Stockholm Stock Exchange, Fact book, 1999, and for the period 1996 to 1998 Capital Market Data Ltd, Database.

Note: Amounts up to 1996 contain only cash issues directed to foreign markets, while amounts from that year onwards contain non-cash issues as well. For comparison, amounts of cash issues directed abroad after 1995 are shown within brackets.

The low level of interest in foreign equity issues shown by Danish firms (see Table 4) may reflect our previous observation that Danish regulators have been liberal in their attitude to cross-border equity activities for many decades. Perhaps, due to this, Danish companies were already part of the global market and had no need to invest in internationalizing their cost of capital? No, the explanation is rather to be found in the size distribution of Danish firms, whereby small and medium-sized firms predominate. This explanation is supported by the fact that Danish firms were involved in foreign issues during the second half of the 1990s; that is to say after they had had the opportunity to benefit from the fund-raising experience of international firms of similar size. There were 33 foreign issues of all categories by non-financial Danish companies in 1995-1999, as compared to only four (cash) issues during the 1980s. If we include issues by financial companies the figures are 35 and 8 respectively. 
In Finland, Norway and Sweden, de jure deregulation started in the mid-1980s. The pattern in the use of issues directed to investors abroad corresponds well with the common view about how de facto integration has proceeded. The eventual (de jure) deregulation that occurred fairly late in the Nordic countries was then just an acknowledgement by the authorities that existing regulations had become eroded and ineffective.

The remaining differences between the countries regarding the corporate use of international issues may then reflect the pace of de facto liberalization, as well as differences in the size distribution of the firms. In the mid-1980s a Nordic toptwenty list of companies contained 16-18 Swedish companies, depending on what variable was used for the ranking (market value, value added, or turnover). The larger Swedish companies were better equipped than the other Nordic companies with knowledge about the financial markets and about how to deal with international financial issues. This may explain why, despite a similar point of departure in terms of de jure liberalization, Swedish firms began directing issues to investors abroad at an earlier date than Finnish and Norwegian firms. During the second half of the 1990s there was a powerful momentum in raising capital abroad. However, as was previously noted, the pattern had changed from cash to other forms of directed issues. Swedish non-financial firms were involved in 54 issues (of all categories) abroad, of which less than ten were cash issues, as compared to 44 issues by Finnish and 24 by Norwegian firms. In addition, Swedish financial institutions launched issues on four occasions, as compared to one occasion by Finnish financial institutions and five by Norwegian.

As we have noted, Danish companies have not shown much interest in international equity issues. In a Nordic comparison they were early in being granted the opportunity to raise capital abroad. Consequently, the first Nordic issue in the post-war period was made by a Danish company: Novo Industri A/S (now Novo Nordisk). However, apart from the interest shown by Novo in 1981 and 1983, issuing activities abroad in the 1980s were limited to a handful of companies: ÖK Holding (1985), UniDanmark (1986 and 1987), Baltica Holding (1988), ISS (1988) and TopDenmark (1988).

In the 1990s euro-equity issues were the predominant type. The international share of the typical Danish issue of DKK 2-400 mill. was 10-20 percent. Three big privatization projects were launched in 1993 and 1994: Girobank in 1993, and 
Copenhagen Airport and Tele Danmark in 1994. They all contained a tranche aimed at an international market. However, the clauses about the right to redistribute between tranches that are always attached to prospectuses make it tricky to estimate the share of international risk capital in every issue. Nonetheless, allowing for this caveat in interpreting euro-equity figures, the large number of issues abroad (of all categories) by Danish listed firms in the 1990s speaks for an increase in the relative importance of foreign equity markets.

The first post-war issue abroad by a Finnish company was undertaken in 1982. The issuer was Kone and the issue was directed to the Swedish market. The choice of market was based on other grounds than cost-of-capital arguments. Sweden continued to be the most popular market for Finnish equity issues abroad for some years. In 1983 Kone, Nokia and Wärtsilä directed issues towards the Swedish market. The two biggest issues that year, however, were a euro-equity issue (Finnish Sugar) and an issue aimed at the US market (Instrumentarium). In terms of amounts raised through international equity issues, 1984 and 1986 were the peak years of the 1980s.

In the mid-1980s Finnish banks started to show an interest in raising capital abroad through directed equity issues: Union Bank of Finland (1985 and 1986) and KOP (two issues in 1988 aimed at two institutional foreign investors, Japanese Nippon Life and Swedish Proventus). By 1987 the big paper and pulp companies were starting to issue abroad: Kymmene (Finland's most important export company at the time) and United Paper Mill. In 1988 Enzo-Gutzeit raised capital through a euro-equity issue.

Between 1989 and 1992 issues directed to foreign investors were low. However, the lifting of restrictions on foreign ownership of Finnish companies, effective from 1 January 1993, triggered a revival of this way of raising capital. In 1993, Nokia raised capital through an issue directed to major financial centers, and Huhtamäki through two foreign issues. In 1994, there were eight issues. Nokia (the biggest issue) and Outokumpu (second biggest) were on the go again. Among the major newcomers were Kemira, Rautaruukki, Valmet and Finnlines. This activity decreased in 1995, when there were only four issues abroad. A dramatic revival, signifying the new pattern, occurred between 1997 and 1999 with 35 issues of all categories directed abroad by non-financial companies.

Since the mid-1980s, and by Nordic standards, Norwegian companies have 
accounted for a large share of foreign ownership. The acquisition of Norwegian shares by foreigners took off in the period 1982-1984. This coincided with the lifting of restrictions on the amount of Norwegian shares a foreign investor was allowed to acquire. However, there were still restrictions on the proportion of shares that foreigners were allowed to hold in any single company. Interest in international equity issues first became really substantial among Norwegian companies at the end of the 1980s. In 1989 Hafslund Nycomed (now Nycomed) raised capital through an issue targeting international institutional investors in London. Later that year equity was raised by Orkla Borregaard through an issue aimed at the UK market and by Storli through a euro-equity issue. In 1990 Kvaerner and Aker targeted international investors with euro-equity issues. In 1992 Hafslund Nycomed placed an issue in the United States and was listed on NYSE. As in the case of firms from other Nordic countries, Norwegian firms increased their raising of non-cash equity abroad in 1997-1999. The bulk of the equity issues (of all kinds) directed abroad in the 1990s occurred during these three years.

When Swedish companies began to approach foreign equity markets, they did so through the flotation of new equity. A major break in this pattern took place in 1981 when the pharmaceutical company Fortia/Pharmacia was introduced NASDAQ, together with a big issue of new shares (big, that is, compared to the size of its market capitalization). Over the period 1981-1993 as many as 30 issues aimed at foreign investors were offered by Swedish companies. The peak as regards the amount raised through equity issues abroad (real as well as nominal terms) occurred in 1983. Nine issues were directed to foreign investors that year. In February, Ericsson announced the third post-war Swedish issue abroad. At the time it was the biggest foreign issue ever made in the Unites States. In real terms it is still one of the biggest Swedish issues abroad. It brought in five times more capital than the second biggest that year (Pharmacia). The capital raised corresponded to about 15 percent of the market value of the company. Pharmacia went for a second round in 1983, trying to repeat its success of 1981 with the creation of value from a very favorable stock market reaction that year (see Oxelheim et al, 1998). The other companies that raised capital from international investors in 1983 were Gambro, Perstorp, Volvo, PLM, Alfa Laval, Sonesson and Aga.

The peak in 1983 was followed by a calm period. Except for an issue by Electrolux in 1986 and by Atlas Copco and Gambro in 1990, the interest of 
Swedish firms in international cash issues was low for the rest of the decade. The interest in foreign equity issues other than cash issues among Swedish firms boomed, however, resulting in 42 issues between 1997 and 1999.

The decline in interest in cash issues on the part of Swedish firms as from the late 1980s is not too puzzling, in view of the abolition in June 1986 of the provision in the Swedish capital controls that required foreign financing for direct investments abroad. As reported in Oxelheim (1990), the management of the 20 largest Swedish multinationals in 1985 found this provision to be a major obstacle.

A feature shared by all the Nordic foreign equity issues - euro-equity and those cash issues directed to a particular foreign market - is the changing size over time of the companies involved. In the 1980s, the companies involved more or less all belonged to the national top-20 groups. In the 1990s, the companies that dared to embark on the venture of raising capital abroad all belonged to the national top100 groups in terms of market capitalization. Pharmaceutical firms were conspicuous among the first out. High levels of intangible assets (and low levels of collaterals) forced this sector to look for new equity rather than loans. Their capital needs relative to the size of the domestic market made foreign equity issues more or less the only alternative.

With respect to the prerequisites for equity market integration, this section has indicated the existence of a two-tier integration. In each of the Nordic markets a block of companies exists that is continuously under scrutiny on the global market. These predominantly large corporations in each one of the Nordic countries have spent big amounts of money on breaking away from their origins in countries with highly regulated and segmented equity markets. They have been richly rewarded for their efforts in terms of global recognition. The cross-border information gap has been closed and they have consequently managed to achieve an international cost-of-capital level (see Oxelheim et al., 1998). This block is more or less perfectly integrated with the global equity market, whereas many of the companies outside it have found themselves too small to afford an international marketing campaign with a view to closing their own cross-border information gaps. The size distribution of Nordic firms indicates that the integrated block of companies is relatively larger in the Swedish equity market than in the other Nordic equity markets.

The bulk of companies listed on the Nordic markets still suffer from cross-border 
information asymmetries, and still belong to a part of the market that is segmented. The indirect information effect for these companies, stemming from the potential interest of foreign investors due to the greater market knowledge they have gained from investing in larger and well-recognized Nordic companies, will only mitigate this situation to a limited extent. A similar pull effect could also arise as a result of foreign companies listing on the Nordic markets. However, Modén and Oxelheim (1997) reported that a more active approach can create value. When listing and issuing abroad occurred simultaneously, companies experienced an 11 percent positive cumulative abnormal return (CAR) in the fiveday period following the announcement of the decision to undertake these operations.

\section{Corporate efforts to maintain control}

As can be seen in Table 5, even though external and internal deregulation had both proceeded at a great pace, there was still plenty of scope towards the end of the 20th century for the managers of Nordic companies to maintain control and thus to influence share prices. When take-over defenses are mobilized, they give rise to segmentation by creating a wedge between the actual price of risk in a particular company and the global price of that risk.

Dullum and Stonehill (1990) report findings from an analysis of take-over defenses used in the restructuring of global industries as a result of a conflict between two paradigms, namely the Corporate Wealth Maximization framework and the Shareholder Wealth Maximization framework. The authors found that a number of take-over defenses were being used in the Anglo-American markets. Among the most common were 1) going private by way of a leveraged buy-out; 2) finding a "white knight"; 3) creating a "poison pill"; 4) granting "golden parachutes" to existing management; 5) changing a firm's corporate charter to require qualified voting on mergers and staggered elections for the board of directors; 6) accusing the take-over entity for anti-trust violations or a breach of the securities laws; 7) paying "greenmail"; and 8) proposing a plan for voluntary restructuring to be carried out by existing management.

A comparison between the findings displayed in Table 5 and similar findings for seven non-Anglo-American countries as reported in Dullum and Stonehill (1990), reveals certain interesting differences. It is a general feature of the markets studied 
by those authors that banks and insurance companies can and do invest heavily in corporate equities. This is not the general case in the Nordic area where banks and insurance companies have not been allowed to hold equity in other companies except in special cases of emergency. Another difference is that the debt/total capitalization ratios have fallen during the 1990s. Moreover, as noted in Section 3 above, governments no longer regulate the (foreign) ownership of industries of strategic value such as defense, banking, insurance, newspaper, television, telecommunications, shipping and aviation. This means that more firms are open to take-overs, especially by foreign firms.

A comparison with Dullum and Stonehill's results shows that the most frequently used defense measure (i.e. used in all 7 of their countries studied), namely relying on a network of close personal relationships, is losing in importance. The second two most frequently used measures that they found were the use of dual classes of voting stocks and the selling of a special issue of voting shares or convertibles to "stable" or "friendly" investors (adopted in 6 of 7 countries). The first of these two defenses is still commonly used, but is declining in importance in all the Nordic countries, whereas the second is not common. Forming a strategic alliance and/or having interlocking boards of directors (as in 5 of 7 countries) is frequently found in Norway and Sweden, but is not common in the other two Nordic countries.

Regulations associated with take-over defenses are also reported in Table 5. They are all aimed at improving the safety and soundness of the financial system, and they work in the direction of increased equity market integration by enhancing transparency and reducing the impact of remaining take-over defenses. As we noted in Section 4, one area that has experienced tougher regulation is the obligation for investors to disclose major increases in their stake in a company. Levels at which the disclosure should take place are legally specified.

In terms of our prerequisites, we can say that the complex interplay between politicians/regulators and managers in the area of prudential issues has generated a weak trend towards increased equity market integration. However, most Nordic companies still have some leeway for protecting themselves, and thus stopping a take-over attempt based on a perceived mis-pricing of the company's share. This also means that hostile take-overs are still unlikely to play an important part in the restructuring process triggered by the current trend towards regionalization and increased integration. 
Table 5 General take-over defenses practiced or in force in the Nordic equity markets at the end of the 1990s.

\begin{tabular}{|c|c|c|c|c|}
\hline & Denmark & Finland & Norway & Sweden \\
\hline $\begin{array}{l}\text { 1. Restrictions on } \\
\text { the number of shares } \\
\text { that can be voted }\end{array}$ & Commonly used & $\begin{array}{c}\text { In some } \\
\text { companies }\end{array}$ & $\begin{array}{l}\text { In some } \\
\text { companies }\end{array}$ & Regulated by law \\
\hline $\begin{array}{l}\text { 2. Restrictions on } \\
\text { foreign ownership of } \\
\text { shares }\end{array}$ & $\begin{array}{c}\text { No restrictions } \\
\text { (restricted shares } \\
\text { no longer } \\
\text { allowed) }\end{array}$ & $\begin{array}{c}\text { No restrictions } \\
\text { (restricted shares } \\
\text { no longer } \\
\text { allowed) }\end{array}$ & $\begin{array}{l}\text { No restrictions } \\
\text { (restricted } \\
\text { shares no } \\
\text { longer allowed) }\end{array}$ & $\begin{array}{c}\text { No restrictions } \\
\text { (restricted shares } \\
\text { no longer } \\
\text { allowed) }\end{array}$ \\
\hline $\begin{array}{l}\text { 3. Dual classes of } \\
\text { stocks }\end{array}$ & $\begin{array}{l}\text { Commonly used } \\
\text { but declining }\end{array}$ & $\begin{array}{l}\text { Commonly used } \\
\text { but declining }\end{array}$ & $\begin{array}{l}\text { Commonly } \\
\text { used but } \\
\text { declining }\end{array}$ & $\begin{array}{l}\text { Commonly used } \\
\text { but declining }\end{array}$ \\
\hline $\begin{array}{l}\text { 4. Provisions in the } \\
\text { corporate charter } \\
\text { that might require a } \\
\text { super majority vote } \\
\text { on a take-over bid }\end{array}$ & $\begin{array}{l}\text { Not commonly } \\
\text { used }\end{array}$ & $\begin{array}{l}\text { Not commonly } \\
\text { used }\end{array}$ & $\begin{array}{c}\text { Not commonly } \\
\text { used }\end{array}$ & $\begin{array}{l}\text { Not commonly } \\
\text { used }\end{array}$ \\
\hline $\begin{array}{l}\text { 5. Selling a special } \\
\text { issue of voting } \\
\text { shares or } \\
\text { convertibles to } \\
\text { "stable" or } \\
\text { "friendly" investors }\end{array}$ & $\begin{array}{l}\text { Not commonly } \\
\text { used }\end{array}$ & $\begin{array}{l}\text { Not commonly } \\
\text { used (if approved } \\
\text { by the general } \\
\text { meeting of } \\
\text { shareholders) }\end{array}$ & $\begin{array}{c}\text { Not commonly } \\
\text { used }\end{array}$ & $\begin{array}{l}\text { Not commonly } \\
\text { used }\end{array}$ \\
\hline $\begin{array}{l}\text { 6. Finding a "white } \\
\text { knight" }\end{array}$ & $\begin{array}{c}\text { Not commonly } \\
\text { used }\end{array}$ & $\begin{array}{c}\text { Possible (but no } \\
\text { case yet) }\end{array}$ & $\begin{array}{c}\text { Not commonly } \\
\text { used }\end{array}$ & $\begin{array}{c}\text { Not commonly } \\
\text { used }\end{array}$ \\
\hline $\begin{array}{l}\text { 7. Control by a } \\
\text { foundation }\end{array}$ & Commonly used & Commonly used & $\begin{array}{c}\text { Not commonly } \\
\text { used }\end{array}$ & Commonly used \\
\hline $\begin{array}{l}\text { 8. Forming a } \\
\text { strategic alliance } \\
\text { and/or interlocking } \\
\text { boards of directors }\end{array}$ & $\begin{array}{l}\text { Not commonly } \\
\text { used }\end{array}$ & $\begin{array}{l}\text { Not commonly } \\
\text { used }\end{array}$ & $\begin{array}{l}\text { Commonly } \\
\text { used }\end{array}$ & $\begin{array}{l}\text { Commonly used } \\
\text { but declining }\end{array}$ \\
\hline $\begin{array}{l}\text { 9. Relying on a } \\
\text { network of close } \\
\text { personal } \\
\text { relationships (i.e., } \\
\text { belonging to "the } \\
\text { establishment") }\end{array}$ & $\begin{array}{l}\text { Commonly used } \\
\text { but declining }\end{array}$ & $\begin{array}{l}\text { Commonly used } \\
\text { but declining }\end{array}$ & $\begin{array}{l}\text { Commonly } \\
\text { used }\end{array}$ & $\begin{array}{l}\text { Commonly used } \\
\text { but declining }\end{array}$ \\
\hline $\begin{array}{l}10 . \text { Government } \\
\text { regulations } \\
\text { controlling } \\
\text { competition and } \\
\text { monopolies }\end{array}$ & Yes, in force & Yes, in force & Yes, in force & Yes, in force \\
\hline $\begin{array}{l}\text { 11. Buy own shares } \\
\text { (excluding share } \\
\text { redemption) }\end{array}$ & $\begin{array}{c}\text { Restricted by law } \\
\text { to max } 10 \% \text { of } \\
\text { shares } \\
\text { outstanding }\end{array}$ & $\begin{array}{l}\text { Possible within } \\
\text { the limits of free } \\
\text { equity capital } \\
\text { to max } 5 \%\end{array}$ & $\begin{array}{l}\text { Not allowed } \\
\text { (restricted by } \\
\text { law) }\end{array}$ & $\begin{array}{c}\text { Not allowed } \\
\text { (restricted by } \\
\text { law). Will in year } \\
2000 \text { be allowed } \\
\text { up to } 10 \%\end{array}$ \\
\hline $\begin{array}{l}\text { 12. Obligations for } \\
\text { investors to disclose } \\
\text { ownership increases }\end{array}$ & $\begin{array}{l}\text { Yes (mandatory } \\
\text { by law for pre- } \\
\text { specified } \\
\text { increases of } \\
\text { ownership) }\end{array}$ & $\begin{array}{l}\text { Yes (mandatory } \\
\text { by law for pre- } \\
\text { specified } \\
\text { increases of } \\
\text { ownership) }\end{array}$ & $\begin{array}{l}\text { Yes (mandatory } \\
\text { by law for pre- } \\
\text { specified } \\
\text { increases of } \\
\text { ownership) } \\
\end{array}$ & $\begin{array}{l}\text { Yes (mandatory } \\
\text { by law for pre- } \\
\text { specified } \\
\text { increases of } \\
\text { ownership) }\end{array}$ \\
\hline
\end{tabular}




\section{Concluding remarks}

From extensive econometric attempts to estimate the extent of equity market integration it has emerged that the markets are neither segmented nor fully integrated. This paper emphasizes the need for a further analysis of the actual causes of segmentation. The "benchmark" case of perfect integration should meet three prerequisites: no cross-border barriers to equity activities, no internal barriers or distorted tax incentives and no cross-border information asymmetries over and above the company-wise asymmetries. Once these requirements can be said to be fulfilled, the last step will be for the econometricians to test whether or not currency and political risks have been properly priced relative to the global standard.

The few published econometric studies of Nordic equity market integration (Mathur and Subrahmanyam, 1990 and Liljeblom, Löflund and Krokfors, 1997) indicate an increasing degree of integration between 1974 and 1993. The empirical observation noted in this paper, based on the complex interplay between politicians/regulators, investors and managers in each individual Nordic market, indicates a strong two-tier integration. The Nordic markets as a whole are not perfectly integrated, but a segment of the market consisting of large companies exposed to detailed scrutiny on the global market, comes very close to it. In a broader perspective, this suggests that econometric studies of integration based on indices are exposed to the "ban of the arithmetic mean", and should be interpreted accordingly. The conflicting results discussed in the introduction may be explained to some extent by differences in terms of the proportions of small and large companies covered by the chosen indices.

As regards barriers to cross-border equity activities, the Nordic markets can be said to have concluded their transition from a state of heavy regulation to become integrated parts of the "global" equity market. Remaining restrictions concern the way an activity is conducted. Since the reason behind these restrictions is taxrelated, they should be associated rather with the category of internal barriers and incentive-distorting measures.

Although the relaxation of taxes on unit trust savings and/or the tax relaxation on dividends and capital income often get the credit for the improvement in the functioning of the Nordic equity markets, a closer examination produces evidence that the general tax structure prevailing in the four Nordic welfare states 
contributes to segmentation. This is particularly obvious in the case of Sweden (the most liquid of the four markets) with its decision in 1995 to reinstall the full double taxation of corporate dividends. Hence, the second group of prerequisites is not fully met in any of the Nordic countries.

As regards the third category of prerequisites to be met for perfect equity market integration, there still seem to be cross-border information gaps in the Nordic case. Corporate investor relations and investment activities suggest that these gaps are gradually going to be closed. Cross-border listing and issues, and international road shows put on by Nordic companies are examples of active measures of the "push" kind, while foreign companies investing (FDI) or looking for risk capital in the Nordic area, and foreign investors' portfolio investment in the area, are all examples of "pull" measures. Indirect pressure on the harmonization of the information content of local companies with that of global companies will also ensue, when domestic investors start investing abroad to an increasing extent.

An issue that calls for further research concerns the extent to which the malign tax incentives still in operation in the Nordic area affect the level of equity integration of the group of genuinely international Nordic companies. Remaining tax-wedges will have to be modeled in some way or another when the time comes for an econometric test of Nordic equity market integration. Further research should also focus on the mis-pricing contingent on the remaining cross-border gaps between corporate governance models and the scope for the Nordic companies to withstand hostile take-over attempts on the part of foreign and domestic firms.

Together with the ongoing globalization of equity markets, the change of attitude among Nordic policy-makers and regulators has triggered a topical debate: should the Nordic national markets form a common Nordic market (like a "refuge"), or should they be allowed to take part in the creation of an EU market place? A joint Nordic market place would be the fourth biggest in Europe in terms of market capitalization. A first step in the direction of co-operation was taken in 1990 with the establishment of NORDQUOTE, which collects and disseminates real time information from each of the four Nordic exchanges via satellite. As a second step a Nordic strategic market alliance was established at the end of the 1990s in response to a corresponding development in other parts of Europe. The alliance NOREX - is between the Copenhagen and the Stockholm Stock Exchanges, with an option for the Oslo and Reykjavik Stock Exchanges to join. The Helsinki Stock Exchange has chosen to join a European alliance (EUREX) with Frankfurt as its 
core, thus preventing for the present, from an institutional point of view, an approach towards a single Nordic equity market.

\section{Notes}

1 I wish to thank Niclas Andrén, Kåre Dullum, Trond Randöy, Art Stonehill and Kaisa Vikkula for valuable comments and insightful discussions, as well as for support in the data gathering process. Financial support from the Saving Bank Foundation Skåne, Sweden, is gratefully acknowledged.

2 These are as described in Oxelheim et al. (1998): 1) asymmetric information available to investors resident in different countries. This includes not only financial data on corporations but also the analytical methods used to evaluate the validity of a security price; 2) different tax regulations, especially with regard to the treatment of capital gains and the double taxation of dividends; 3 ) regulations on security markets; 4) alternative sets of optimal portfolios from the perspective of investors resident in one equity market compared to investors resident in other equity markets; 5) different agency costs for firms in bank-dominated markets compared to firms in the Anglo-American markets; 6) different levels of risk tolerance, such as debt ratios, in different countries; 7) differences in perceived foreign exchange risk, especially with respect to operating and transaction exposure: 8) political risk such as unpredictable government interference in capital markets and arbitrary changes in rules; 9) take-over defenses that differ widely between the AngloAmerican market, characterized by one-share-one-vote, and other markets featuring dual classes of stock and other take-over barriers; and 10) the level of transaction costs involved in purchasing, selling and trading securities.

3 Based on the idea of an optimal order for deregulation, the elimination of internal wedges and incentive distortions should precede the abolition of capital controls. For a further discussion of issues related to the optimal order for deregulation, see Oxelheim (1996).

4 Apart from any purely macro-policy reasons, the politicians have accordingly aimed historically at receiving cheap financing and protection from the foreign take-overs of domestic "jewels".

5 The fifth Nordic country, Iceland, is not included in this paper. Iceland has a very young equity market and has only recently embarked on the route to equity market integration.

\section{REFERENCES}

Arshanapalli, B. and J. Doukas, 1993, International stock market linkages: Evidence from the pre- and post-October 1987 period, Journal of Banking and Finance 17, 193-208.

Bansal, R., Hsieh, D. and R. Viswanathan, 1993, A New Approach to International Arbitrage Pricing, Journal of Finance 48, 1231- 1262.

Bertero, E. and C. Mayer, 1990, Structure and Performance: Global Interdependence of Stock Markets around the Crash of October 1987, European Economic Review 34, 1155-1180.

Black, F., 1974, International Capital Market Equilibrium with Investment Barriers, Journal of Financial Economics 1, 337-352.

Cho, D., Eun, C., and L. Senbet, 1986, International arbitrage pricing theory: an empirical investigation, Journal of Finance 41, 313-330.

Cooper, I and E. Kaplanis, 1994, Home Bias in Equity Portfolios, Inflation 
Hedging and International Capital Market Equilibrium, Review of Financial Studies 7, 45-60.

Dullum, K..B. and A. Stonehill, 1990, Corporate Wealth Maximization, Takeovers and The Market for Corporate Control, Nationalökonomisk Tidsskrift 1, 49-58.

Dumas, B., 1994, Partial Equilibrium versus General Equilibrium Models of the International Capital Market in: F. van der Ploeg (ed.), The Handbook of International Macroeconomics, Blackwell, (Cambridge, MA).

Erb, C.B., C.R. Harvey and T.E. Viscanta, 1994, Forecasting International Equity Correlations, Financial Analysts Journal 50, November/December, 32-45.

Errunza, V. and E. Losq, 1985, International asset pricing under mild segmentation: theory and test, Journal of Finance 40, 105-124.

Eun, C. and S. Janakiramanan, 1986, A Model of International Asset Pricing with a Constraint on the Foreign Equity Ownership, Journal of Finance 41, 897-914.

Eun, C. and S. Shim, 1989, International transmissions of stock market movements, Journal of Financial and Quantitative Analysis 24, 241-255.

French,K. and J. Poterba, 1991, Investor Diversification and International Equity Markets, American Economic Review, Papers and proceedings of the 103 annual meeting of AEA, 222-226.

Glen, J. and P. Jorion, 1993, Currency Hedging for International Portfolios, Journal of Finance 48, 1865-1886.

Gultekin, M., Gultekin, N. and A. Penati, 1989, Capital controls and capital market segmentation, Journal of Finance 44, pp. 849-869.

Hamao, Y. Masulis, R.W. and V. Ng, 1990, Correlations in Price Changes and Volatility across International Stock Markets, Review of Financial Studies 3, 281-307.

Harvey, C., 1991, The world price of covariance risk, Journal of Finance 46, 111157.

Hietala, P.T., 1989, Asset Pricing in Partially Segmented Markets: Evidence from the Finnish Market, Journal of Finance 44, 697-718.

Ibbotson, R., Siegel, L. and K. Love, 1985, World Wealth: Market Values and Returns, Journal of Portfolio Management 11, 4-23.

IBFD, 1998, European Tax Handbook (International Bureau of Fiscal Documentation, Amsterdam).

Ibrahimi, I., Oxelheim, L. and C. Wihlborg, 1995, Macroeconomic Fluctuations and International Stock Markets, in: Aggarwal, R. and D.Schirm (eds.), Global Portfolio Diversification (Academic Press, New York)

Jorion.P. and E. Schwartz, 1986, Integration versus segmentation in the Canadian stock market, Journal of Finance 41, 603-613.

Jorion, P., 1989, Asset Allocation with Hedged or Unhedged Foreign Stocks and Bonds" Journal of Portfolio Management, Summer, 49-54.

Jorion, P., 1985, International Portfolio Diversification with Estimation Risk, Journal of Business 58, July, 259-278.

Kaplanis, E., 1988, Stability and Forecasting of the Co-movement of Measures of International Stock Market Returns, Journal of International Money and Finance 7, February, 63-75.

King, M, Santana, E. and S. Whadwani, 1994, Volatility and Links between National Stock Markets, Econometrica 62, 901-933.

Korajczyk, R. and C. Viallet, 1989, An empirical investigation of international 
asset pricing, Review of Financial Studies 2, 553-587.

Lau, S.T. and J.D. Diltz, 1994, Stock Returns and the Transfer of Information between the New York and Tokyo Stock Exchanges, Journal of International Money and Finance 13, April, 211-222.

Liljeblom, E., Löflund, A. and S. Krokfors, 1997, The Benefits from International Diversification for Nordic Investors, Journal of Banking and Finance 21, 469490.

Lin, W.L., Engle, R.F. and T. Ito, 1994, Do Bulls and Bears Move across Borders?- International Transmission of Stock Returns and Volatility, Review of Financial Studies 7, Fall, 507-538.

Longin, F. and B. Solnik, 1995, Is the International Correlation of Equity Returns Constant: 1960-1990?, Journal of International Money and Finance 14, 3-26.

Mathur, I. and V. Subrahmanyam, 1990, Interdependence among the Nordic and U.S. Stock Markets, Scandinavian Journal of Economics 92, 587-597.

Modén, K-M. and L. Oxelheim, 1997, Why Issue Equity Abroad - Corporate Reasons and Stock Market Responses, Management International Review 37, 223-241.

Naranjo, A. and A. Protopapadakis, 1997, Financial market integration tests: an investigation using US equity markets, Journal of International Financial Markets, Institutions \& Money 7, 93-135.

Odier, P. and B. Solnik, 1993, Lessons for International Asset Allocation, Financial Analysts Journal, March/April, 63-77.

OECD, 1991, Taxing profits in a global economy (OECD,Paris).

Oxelheim, L., 1996, Financial Markets in Transition - Globalization, Investment and Economic Growth (Routledge, London and New York).

Oxelheim, L., 1990, International Financial Integration (Springer Verlag, Berlin).

Oxelheim, L., Stonehill, A., Randöy, T., Vikkula, K., Dullum, K.B. and K-M. Modén, 1998, Corporate Strategies to Internationalise the Cost of Capital (Copenhagen Business School Press, Copenhagen).

Roll, R., 1988, The International Crash of October 1987, Financial Analysts Journal 44, 19-35.

Solnik, B., 1996, International Investments (Addison Wesley, Reading, MA).

Stapleton. R.C. and M.G. Subrahmanyam, 1977, Market Imperfections, Capital Market Equilibrium and Corporation Finance, Journal of Finance 32, May, 307319.

Stjernborg, S., 1987, Utrikeshandel med svenska aktier, Kredit och Valutaöversikt 4,27-35, Stockholm.

Stultz, R., 1981, A model of international asset pricing, Journal of Financial Economics 9, 383-406.

Susmel, R. and R.F. Engle, 1994, Hourly Volatility Spillovers between International Equity Markets, Journal of International Money and Finance 13, 325.

Tesar, L. and I. Werner, 1995, Home Bias and High Turnover, Journal of International Money and Finance 14, 467-492.

Wheatley, S.,1988, Some tests on international equity integration, Journal of Financial Economics 21, 177-212. 